\title{
Innovations in veterinary markets: opinion leaders' social capital
}

\author{
Ignat Kulkov \\ Faculty of Science and Engineering, Åbo Akademi University, Turku, Finland \\ Wilhelm Barner-Rasmussen and Maria Ivanova-Gongne \\ School of Business and Economics, Åbo Akademi University, Turku, Finland \\ Anastasia Tsvetkova \\ Faculty of Science and Engineering, Åbo Akademi University, Turku, Finland \\ Magnus Hellström \\ Faculty of Science and Engineering, Åbo Akademi University, Turku, Finland and School of Business and Law, \\ University of Agder, Kristiansand, Norway, and \\ Kim Wikström \\ Faculty of Science and Engineering, Åbo Akademi University, Turku, Finland
}

\begin{abstract}
Purpose - This study aims to identify how the personal social capital of opinion leaders contributes to the market adoption of start-up innovations. Design/methodology/approach - A design-oriented case study is undertaken with a start-up company focusing on the development and commercialization of innovations in the veterinary market. Based on a literature review, the authors examine the social capital in value creation and the role of opinion leaders and use qualitative methodology and semi-structured in-depth interviews to collect data.

Findings - The adoption of innovations could start with opinion leaders that will later share their experience with other members of the professional community. In turn, social capital allows for creating a collaboration between start-ups and leaders based on a number of specific parameters.

Originality/value - This paper contributes to marketing literature by providing new insights regarding collaboration between start-ups and opinion leaders. The collaboration between opinion leaders and start-ups could be implemented not only in the veterinary industry but also in other industries with minor adaptations. Authors demonstrate how the social capital of external stakeholders may be used as a resource of the company for business development. The main contribution of this study is to demonstrate that social capital could be used as a parameter for the adoption of innovations. The key parameters that allow creating cooperation between start-up and opinion leader have been identified.
\end{abstract}

Keywords Social capital, Opinion leader, Adoption of innovations, Start-ups

Paper type Research paper

\section{Introduction}

The main obstacle for start-ups is not the creation of an invention, but commercialization of the result (Van de Ven et al., 1984; Baum and Silverman, 2004) that is the process of developing, adopting and bringing innovation to the market. A successful innovation process requires an original, resultsoriented approach (Kumar et al., 2019). Viable development strategies and commercialization processes for start-up inventions are often associated with the external environment in which the commercialization takes place or with the commercialization environment itself (Gans and Stern, 2003; Eesley et al., 2014; Schiavone and Simoni, 2019). The external environment sets the boundary conditions so that a

The current issue and full text archive of this journal is available on Emerald Insight at: https://www.emerald.com/insight/0885-8624.htm

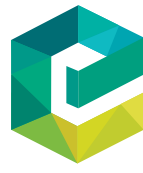

Journal of Business \& Industrial Marketing $36 / 13$ (2021) 1-14

Emerald Publishing Limited [ISSN 0885-8624]

[DOI 10.1108/JBIM-02-2020-0098] company may create unique value for the customer and the circumstances for this process to occur. The adoption of breakthrough inventions could be influenced by the features of the market, industrial barriers and/or priorities in the development of other areas of the economy (Sykes and Block, 1989; Jayashankar et al., 2018; Sternad et al., 2019; Udagedara and Allman, 2019).

In uncertain business conditions, social capital could become an important resource (Freeman and Engel, 2007; Gabbay and Leenders, 2001); broadly speaking, it concerns "the

(C) Ignat Kulkov, Wilhelm Barner-Rasmussen, Maria Ivanova-Gongne, Anastasia Tsvetkova, Magnus Hellström and Kim Wikström. Published by Emerald Publishing Limited. This article is published under the Creative Commons Attribution (CC BY 4.0) licence. Anyone may reproduce, distribute, translate and create derivative works of this article (for both commercial and non-commercial purposes), subject to full attribution to the original publication and authors. The full terms of this licence may be seen at http://creativecommons.org/licences/by/4.0/legalcode

Received 14 February 2020

Revised 5 June 2020

Accepted 6 June 2020 
significance of relationships as a resource for social action" (Nahapiet and Ghoshal, 1998: 242) and was initially defined as assets that have value for society and individuals, for example, communication and fellowship between people or groups (Coleman, 1988). In this paper, we follow the term "social capital" as defined by Nahapiet and Ghoshal (1998, p. 243): "the sum of the actual and potential resources embedded within, available through and derived from the network of relationships possessed by an individual or social unit."

This definition entails that social capital:

- is based on relationships,

- gives access to relational resources such as trust, contacts and shared mindsets (Nahapiet and Ghoshal, 1998) and thereby

- brings cost reductions and benefits to those who possess it.

The concept has been used across a range of social sciences, and a significant part of the research focuses on its role in the creation of the public good (Fukuyama, 2001; Lin, 2017). However, there is also a lively discussion on social capital as the property of individuals, and the relationship between public and private social capital has received much scrutiny. In a business management context, Kostova and Roth's (2003) conceptualization of the process, through which micro (private) social capital is converted into macro (organizational) social capital and vice versa, is widely regarded as seminal. This draws our attention to how the social capital of key individuals may play a role in the market adoption of start-up firms' innovations.

Industry opinion leaders are members of society, groups or communities that other members turn to for opinions or advise (Chan and Mistra, 1990; Katz et al., 2017). Researchers also note that collaboration with opinion leaders has a positive effect on business development through increased sales, brand recognition and more accurate audience targeting (Lindiwe, 2017; Lang et al., 2018). From a theoretical point of view, current research argues that opinion leaders could become a significant resource for promoting medical and technological innovations (Laurell, 2018; Jeong et al., 2018). From a practical standpoint, due to the lack of resources, start-ups tend to search for market advantage in various ways. The social capital of leading market participants could become significant in increasing the chances of success. However, there is still a question of how the social capital of opinion leaders could become an important parameter for the adoption of innovation in the market. We chose to focus on the veterinary industry, which has attracted the attention of social researchers during the past decade (Henry et al., 2016; Armitage-Chan and Jackson, 2018; Pearson et al., 2018). Unlike human medicine, where new products and companies are constantly appearing, veterinary medicine is less dynamic but is nevertheless in great need of innovation. In general, the business models of companies producing veterinary products are conservative despite the growing demand from veterinarians and animal owners (Neill et al., 2018). The veterinary industry is a typical mature market characterized by a state of equilibrium, a lack of innovations and limited growth within the studied timeframe (Flammini et al., 2017; Groh, 2018). Currently, start-ups and other veterinary companies collaborate with practicing veterinarians. However, these veterinarians are regular practitioners; cooperation with them carries little additional value and does not distinguish the company in the market. We see a gap between understanding the importance of using opinion leaders for business development and for start-up companies. Researchers do not identify important parameters in the emergence of cooperation between start-ups and opinion leaders.

This problem setting leads us to the following research question: can the social capital of opinion leaders contribute to the market adoption of start-up innovations, and if so, how? Thus, the aim of the study is to describe the collaboration of opinion leaders and start-ups and to identify if and how the personal social capital of opinion leaders contributes to the market adoption (development, adoption and commercialization) of start-up innovations. This incorporates the question of the conditions in which opinion leaders would be willing to extend their personal social capital to the activities of the start-up organization. To explore how the social capital of opinion leaders may influence the development, adoption and commercialization of start-up innovations in difficult market conditions, we undertook a case study of a start-up with three projects that focuses on the development and commercialization of scientific innovations in the veterinary industry. The contribution of the study is twofold. First, we add to the research on social capital as a marketing resource for the adoption of innovations (Khoshmaram et al., 2018; Akman et al., 2018). Second, we explore the collaboration between opinion leaders and companies (Van den Nieuwboer et al., 2016; Truog and Curtis, 2018). Finally, we provide practical recommendations for companies that plan to implement social capital in business development.

The article is organized as follows. First, we examine the literature on social capital and opinion leaders, their role in business development and how they collaborate with companies. We also introduce the veterinary industry. We then describe our research method and present the case company with a focus on its approach to collaboration with opinion leaders in the development of three different products. Based on this, we identify the key parameters that contribute to the emergence and strength of cooperation between opinion leaders and start-ups. After that, we discuss the impact of our research on theory and practice.

\section{Theoretical background}

\section{Social capital in entrepreneurship}

Social capital contributes to the formation of networks at different levels for the exchange and ownership of resources and increases trust between partners (Tsai and Ghoshal, 1998; King, 2004). It is considered both a private good that benefits the actors (Coleman, 1988) and a public good that benefits society or organizations (Woolcock and Narayan, 2000). Public good is defined as trust and mutuality that promotes and offers productive ways for individuals to interact in society (Dubos, 2017), creating value at both levels. Here, we consider the combination of public and private good as the interaction of individuals within an organization and the creation of value for the industry. We follow Kostova and Roth's (2003) argument that micro-level (personal) social capital can be converted into macro-level (organizational) social capital through the activities of key individuals and their interactions with other individuals in their respective networks. 
Scholars in sociology, international business and political science (Fukuyama, 2001; Inkeles, 2000; Onyx and Bullen, 2000; Lindstrand et al., 2011) have explored the role of social capital for value creation at the regional or national level, while researchers in psychology, leadership and management have explored its value for, e.g. organizations and families (Brass and Krackhardt, 1999; Nahapiet and Ghoshal, 1998; Khoshmaram et al., 2018; Krishen et al., 2019; Sadik-Rozsnyai and Bertrandias, 2019; Badawi and Battor, 2020). A red thread among many studies is the importance of social capital in determining social networks (Nahapiet and Ghoshal, 1998; Molina-Morales and Martínez-Fernández, 2010). People need social networks to form and achieve social and psychological goals. Moreover, social networks have both strong and weak links (Putnam, 1993; Granovetter, 1997). Strong links contribute to building trust within the network. In turn, weak links contribute to the connection of new networks, an increase in resources and expertize. These links are equally important for individuals, organizations and society. The social capital and network position of an individual or organization determine their ability to profit from the available resources of the network (Brass and Krackhardt, 1999; Krishen et al., 2018; Masiello and Izzo, 2019).

Entrepreneurs are part of social networks; they use social capital for entrepreneurial activities (Julien, 2018; LopezNicolas et al., 2020) and to identify opportunities for business growth (Hoang and Antoncic, 2003). Social capital supports risk-taking (Zarei et al., 2019), which contributes to sustainability in business management (Reddy et al., 2019). The main advantage of using social capital for entrepreneurs is access to information and resources for doing business. For example, networks provide information on industry leaders (Gabbay and Leenders, 2001), and start-up entrepreneurs benefit from the creation and exchange of social capital (Semrau and Hopp, 2016; Xu, 2016; Akman et al., 2018). The social capital of company founders affects the development of the business model and the success of the company in the early stages of development. In turn, social ties in the scientific and high-tech fields contribute to the formation of new ventures.

Mentorship in business development is an important aspect of social capital. A mentor that has more experience and advanced knowledge supports the development of new entrepreneurial skills (Fowler et al., 2007). Such leaders foster a positive entrepreneurial image, reduce the uncertainty of inexperienced young entrepreneurs, and are successful models to follow (McGowan et al., 2015).

Thus, social capital plays an important role in entrepreneurship and forms social interaction between the participants of the business ecosystem (Jack, 2005). Social capital in business activities facilitates connections and increases social trust (Putnam, 2001; McKeever et al., 2014). A community that shares common values considers social capital as a collective benefit (Jack and Anderson, 2002).

Although the existing literature suggests that social capital plays a significant role in the creation of value by companies (Tsai and Ghoshal, 1998; Sanchez-Ruiz et al., 2019), formal analyzes of the specific conditions and parameters for the emergence of interaction between partners are scarce. Some of the available studies that explore the collaboration of opinion leaders and small companies are mostly descriptive and relate to social media (Cho et al., 2012). We help fill this gap by offering an analysis of how social capital affects the adoption of innovation by the market in general and by identifying the key factors leading to the interaction of opinion leaders and start-ups in particular.

\section{Product innovation}

A market-oriented company introduces product innovation in the market to meet the needs of the customers (Carboni and Russu, 2018; Lukas and Ferrell, 2000). Product innovations typically satisfy needs through radical changes in product properties (Heij et al., 2020). The development of new products may provide a continuous competitive advantage in the market.

New product development starts with the idea's generation phase. Researchers insist on a systematic internal search for new ideas based on internal information (for example, from sales, marketing and research and development (R\&D) departments) and external data (customer wishes, actions of competitors and suppliers) (Frishammar et al., 2019; Pertuz and Pérez, 2020). In turn, the modern knowledge-based economy often implies the intersection of different fields of knowledge to generate an idea for the new product (Arfi and Hikkerova, 2019). This is followed by the idea selection stage. At this stage, the least promising ideas for realization are eliminated. The number of ideas that are accepted and transferred to the commercial production stage is reduced, and the cost of each subsequent stage increases (Ramadani et al., 2019). Ideas are evaluated by a team of developers with the involvement of independent professionals who have the proper competence (Sarangee et al., 2019). Researchers also pay attention to the involvement of customers in the initial stages of development (Frohlich and Westbrook, 2001; Turner et al., 2018). However, opinions on this subject differ. On the one hand, customers are directly interested in solving existing problems and are aware of the needs of their industry. On the other hand, most customers are focused on their own narrow tasks and cannot sufficiently predict the direction of market change. Choosing the right consultant or partner at this stage could save significant company resources.

Researchers have been studying R\&D as one of the key processes in gaining a competitive advantage for many decades (Schumpeter, 1942; Song and Thieme, 2006; Coad et al., 2019). A special place in such research is given to the technological innovations of products or services that contribute to the appearance of new products on the market (Heij et al., 2020; Cooper, 2019). However, researchers estimate the relationship between $R \& D$ and product innovation differently.

Some researchers declare a positive relationship between R\&D and successful product innovations (Baumann and Kritikos, 2016; Song and Thieme, 2006), others report a lack of dependence (Raymond and St-Pierre, 2010) and some state a negative relationship (Coombs and Bierly, 2006). Nevertheless, the majority of researchers state that product innovation demonstrates the effectiveness of the company's R\&D processes and its ability to commercialize 
knowledge. New product development starts by identifying key parameters that create value for the existing customers (Seidel, 2007; Walter et al., 2001). New products are created as a way to introduce new forms or ideas to the market, provided that the needs of the consumer are met.

Product innovation is mainly associated with product development teams. On the one hand, studies show that uniting people with different backgrounds, personal characteristics and good interpersonal communication leads to success more often (Brockman et al., 2010; Carbonell and Rodríguez Escudero, 2019). On the other hand, permanent team formation decreases the efficiency of development by reducing the need for change (Schwab and Miner, 2008). Thus, the formation of start-ups or small project teams in established companies with varying structures increases the chances of success. Recent research in product innovation claims that the experience level of the developers could become a critical factor for project success (Forti et al., 2020). Experienced developers or project leaders could serve as a source of ideas and their validation, and they are influential in following product development. Different areas of expertize allow the formation of knowledge that leads to a synergistic effect in new projects, especially at the intersection of several areas (Evans et al., 2004). An appropriate way of selecting the most valuable team members could be the basis for a successful development strategy for the company or a product innovation project.

While know-how within the founding team is crucial for the creation of innovations within start-ups (Dakhli and De Clercq, 2004), the knowledge might be limited due to a lack of necessary (human) resources. Thereby, external knowledge through its social capital is crucial for start-ups in innovation processes and in general performance (Pirolo and Presutti, 2010). During early growth, start-ups' innovation performance can benefit both from weak and strong social ties (Alguezaui and Filieri, 2010; Pirolo and Presutti, 2010). Further, we propose that it is necessary to consider the role of an industrial opinion leader for product innovation and of its social capital for promoting products on the market. Compared to strong ties such as family and friends, an opinion leader usually represents itself as weak. As postulated by previous literature, weak ties are more likely than strong ones to 'be 'local bridges' to distant contacts possessing unique information that reinforces the development of innovative solutions during the start-up's growth" (Pirolo and Presutti, 2010 p. 204).

\section{The role of opinion leaders}

Researchers have been identifying the parameters of opinion leaders for many decades, as the idea of the "two-step flow" (Lazarsfeld et al., 1944), a theory that suggests that the majority of people form their views based on the influence of opinion leaders who, in turn, are influenced by the media. This study was the impetus for creating the theme that led to the classic studies of Merton (1949) and Coleman et al. (1957). While demonstrating the difficulty of clearly determining opinion leaders a priori, this research and later work in the same vein showed that opinion leaders possess better competence and knowledge than the majority of potential customers. For example, Chan and Misra (1990) studied opinion leaders and how they differ from other professionals. Their research highlights public individualization, personal involvement and product familiarity as fundamental for identifying an opinion leader. However, not all researchers agree on the role of opinion leaders. For instance, Bennett and Manheim (2006) insist that opinion leaders decrease effectiveness because of the new classical media's development and transformation. Social media allows direct access to customers without opinion leaders that is a "one-step flow." However, this approach is more suitable for everyday goods. The more recent "influencer" concept differs from opinion leaders in that most influencers (a person or group with power over a certain audience) use their influence to promote goods and services commercially.

The collaboration of business and influencers has accelerated with the development of social media in fast-moving consumer goods, retail and tourism (Peters and Shields, 2017; Ong and Ito, 2019). The "mediatization" of society and the increase in media accessibility contribute to changes in the dynamics of opinion leadership (Krotz, 2009; Magno and Cassia, 2019). This transformation plays a great role by mixing previously separate media and online media (Schäfer and Taddicken, 2015). Momtaz et al. (2011) studied social media participants and propose a methodology for identifying opinion leaders. The parameters of opinion leaders have different weight and influence on the audience, contributing to a better ranking and determination of effectiveness. Zhang et al. (2015) dispute the role of opinion leaders at different stages of promoting a product or company on social media. This study proposes new marketing techniques for assessing and increasing social media influence, namely, engaging opinion leaders after forming initial interest.

Opinion leaders' involvement in the promotion of a product or service in medicine has been studied by many researchers (Flodgren et al., 2007; Van den Nieuwboer et al., 2016). For example, researchers pay close attention to the role of opinion leaders in the pharmaceutical industry (Sismondo and Chloubova, 2016; Truog and Curtis, 2018). However, financial obligations between opinion leaders and large companies influence the impartiality of transferred knowledge (Liberati and Magrini, 2003; Sismondo, 2017).

In contrast, researchers have extended little interest in the role of opinion leaders' collaboration with start-ups. The vast majority of start-ups have limited resources to develop and promote products (Davila et al., 2003; Muñoz-Bullon et al., 2015; Liu et al., 2017). Opinion leaders may have a significant role in product development and tests (Gakhar and Chahal, 2016). Mentors of business incubators provide services and create a favorable environment for the development of entrepreneurship (Dutt et al., 2016). Mentors and advisors become leaders who form and support the founders of companies.

Against this background, creating long-term relationships with opinion leaders may be of great interest to many companies. Regardless of age, size and revenue, organizations face a specific set of factors that complicate such cooperation (Gustavsson et al., 2018). Financial resources (George, 2005) and the competence of employees (Mishina et al., 2004) are the main factors. Such restrictions are investigated for medium and large companies (Gilmore et al., 2001) and start-ups (Fillis, 2002). Besides financial restrictions, other hindrances inherent 
in start-ups include a lack of time and knowledge (Bocconcelli et al., 2018). Although cooperation with opinion leaders does not always imply a large amount of financial resources for startups (Sahelices-Pinto and Rodríguez-Santos, 2014), a lack of resources may limit cooperation. However, there is no research about this or about the factors that are important for opinion leaders when they choose to engage in collaborative projects with companies.

\section{The veterinary industry}

Veterinarians, like their colleagues from the human medical field, want to see new products on the market (Valdez et al., 2018; Pearson et al., 2018). However, although new products and services appear, the majority are not breakthroughs or radically innovative (Roberts, 2017). The veterinary industry differs from human medicine and most other industries in the development, adoption and commercialization of innovations. Traditionally, there are two main ways to create new products in the veterinary market. First, there are personal attempts by veterinarians to solve existing problems: veterinarians tend to develop new devices because engineers and materials scientists tend to focus on products for the human market. The advantage of this approach is the practical experience of the veterinarian and the ability to test and commercialize a new product. A significant drawback, therefore, is the lack of expert input from other areas. Second, manufacturing companies produce new products and offer them to customers. However, a lack of resources and cooperation with breakthrough technologies lead to the replication or little modernization of existing products. These closed business models (Chesbrough, 2010) lead to significant conservatism in the veterinary industry (Bers et al., 2014). Yet, because innovations can be developed faster within a network of trust between collaborators (Chow and Chan, 2008), start-ups require open business models for internal and external cooperation (Chesbrough, 2010). Compared to the human medical market, then, few companies consider entering the veterinary industry.

Opinion leaders are an underrated resource that could facilitate small companies' entry into the veterinary industry. Their social capital could be an affordable value that enables the adoption of products or services in the veterinary market.

\section{Methodology}

This article is based on a qualitative single case study that allows for in-depth knowledge of existing issues and adds new knowledge to theory (Locke, 2000). The case company, TraceRay, is characterized by a cooperation with opinion leaders based on new principles that are significantly different from accepted standards in the industry. Single case studies are a valid approach if the case in consideration appears to be an extreme rather than a typical one (Yin, 2011).

The study also uses the design-oriented action research method, which eschews the traditional positivist emphasis on clear variables and unequivocally defined relationships to test various approaches in real-life settings and explore their outcomes (Denscombe, 2014). The research group is actively involved in the work of the focal company, providing detailed insight and data access. We use three of the company's projects to explore its collaboration with opinion leaders of the veterinary industry. The projects are based on innovation and patented products, but their market impact differs. Each project is unique in terms of the product and the participating opinion leaders. This supports the expansion of the existing theory by providing an opportunity to evaluate the interaction of key participants with different parameters (Eisenhardt, 1989). TraceRay constitutes a relevant case, as it is highly dependent on collaboration with opinion leaders in the market; moreover, it is a suitable case to study, as it offers a new business model in a conservative market (Neill et al., 2018). The company offers unique patented products based on university research, as well as a new approach to developing products for the market and promoting them with the support of opinion leaders.

In 2019, the key shareholders involved in the commercialization of the invention were interviewed, including the CEO and CTO of the start-up, a private investor, practicing veterinarian consultants and project managers. We interviewed all the participants who had the ability to make decisions in the focal projects. The main points of discussion were to determine the company's potential for innovation in the veterinary market, discuss challenges and opportunities and identify the role of opinion leaders for the projects. Table 1 provides information about the interviewees, discussion topics, date and duration of the meetings. Furthermore, additional information was obtained through phone conversations.

The initial list of topics for analysis was formed through discussions with the CEO of the company. In subsequent interviews with other company representatives and opinion leaders, we compared this list with new opinions and supplemented them. We met with each of the company representatives and opinion leaders at least twice during the study to clarify the new findings, and we participated in the company's monthly meetings, where their business strategy was discussed. Our analysis contributes to a deeper understanding of the emergent processes that occur between the participants. Different participants emphasized different topics, complementing the studied phenomenon and increasing the objectivity and credibility of the study.

We used a constant comparison of the obtained information to identify patterns of interaction between the participants and their development over time (Shah and Corley, 2006). Identifying certain issues influenced the follow-up interviews, for example, helping determine parameters to be considered or specified in more detail. The obtained data were analyzed until we reached a certain saturation and did not receive new information from the participants.

\section{Description of the case firm and studied projects}

Established in April 2015, TraceRay is a small Finnish start-up company that focuses on the $\mathrm{R} \& \mathrm{D}$ of veterinary products. The company's founders have considerable experience in biomaterials science and implant development. The veterinary industry was chosen as the field of particular initial interest because it has a more relaxed regulation and less competition. Consequently, the need for investment was considered to be reasonably low, and therefore, it was affordable. The downside of the veterinary market is that it is smaller than the human market. 
Table 1 Key online and offline meetings with the studied company and partners

\begin{tabular}{|c|c|c|}
\hline Representative & Time & Major discussed topics \\
\hline CEO of TraceRay & $\begin{array}{l}\text { January } 2019, \\
2 \mathrm{~h}\end{array}$ & $\begin{array}{l}\text { - Foundation of the company } \\
\text { - The innovative idea } \\
\text { - Commercialization of the university research } \\
\text { - Background } \\
\text { - Investor relations } \\
\text { - Competitors } \\
\text { - Collaboration with partners } \\
\text { - Future plans }\end{array}$ \\
\hline СТО of TraceRay & $\begin{array}{l}\text { January } 2019, \\
1.5 \mathrm{~h}\end{array}$ & $\begin{array}{l}\text { - Advantages } \\
\text { - Product development } \\
\text { - Collaboration with partners } \\
\text { - Future plans }\end{array}$ \\
\hline Private investor of TraceRay & $\begin{array}{l}\text { January 2019, } \\
1 \mathrm{~h}\end{array}$ & $\begin{array}{l}\text { - Reasons for cooperation } \\
\text { - Future plans }\end{array}$ \\
\hline CEO, CTO and private investor of TraceRay, veterinarians & $\begin{array}{l}\text { February } 2019, \\
2.5 \mathrm{~h}\end{array}$ & $\begin{array}{l}\text { - Plate development } \\
\text { - Protective collars }\end{array}$ \\
\hline Project manager of intelligent veterinary implants & $\begin{array}{l}\text { February 2019, } \\
0.5 \mathrm{~h}\end{array}$ & - Product development \\
\hline Project manager of intelligent veterinary implants, Opinion leader 1 & $\begin{array}{l}\text { February } 2019, \\
1 \mathrm{~h}\end{array}$ & - Product development \\
\hline СТO of TraceRay & $\begin{array}{l}\text { February } 2019, \\
1 \mathrm{~h}\end{array}$ & $\begin{array}{l}\text { - Sensor implementation } \\
\text { - Data transfer }\end{array}$ \\
\hline CEO, CTO and Charlie Care project manager of TraceRay & $\begin{array}{l}\text { March 2019, } \\
2 \text { h }\end{array}$ & - Protective collars prototypes \\
\hline Project manager of Charlie Care, veterinarians & $\begin{array}{l}\text { March 2019, } \\
1 \mathrm{~h}\end{array}$ & - Product development \\
\hline Project manager of Smart Jockey & $\begin{array}{l}\text { April 2019, } \\
1.5 \mathrm{~h}\end{array}$ & - Product development \\
\hline CEO, Project manager of Smart Jockey, Opinion leader 2 & $\begin{array}{l}\text { May 2019, } \\
1.5 \mathrm{~h}\end{array}$ & - Product development \\
\hline Opinion leader 1 & $\begin{array}{l}\text { May 2019, } \\
1 \mathrm{~h}\end{array}$ & $\begin{array}{l}\text { - Collaboration with TraceRay } \\
\text { - Own research and business development }\end{array}$ \\
\hline Opinion leader 2 & $\begin{array}{l}\text { June } 2019, \\
1 \mathrm{~h}\end{array}$ & $\begin{array}{l}\text { - Collaboration with TraceRay } \\
\text { - Product development }\end{array}$ \\
\hline Project manager of Charlie Care, manufacture manager & $\begin{array}{l}\text { June } 2019, \\
0.5 \mathrm{~h}\end{array}$ & - Product development \\
\hline CEO & $\begin{array}{l}\text { June 2019, } \\
1 \mathrm{~h}\end{array}$ & $\begin{array}{ll}\text { - } & \text { Updating results } \\
\text { - } & \text { Summarizing }\end{array}$ \\
\hline
\end{tabular}




\section{Projects included in the study}

The first targeted product of the company is intelligent veterinary implants to treat bone fractures in dogs. The product is multifunctional and can be tailored to meet specific clinical needs. Overall, the R\&D process of the product is based on close collaboration between veterinary market opinion leaders, veterinary surgeons and biomaterials researchers. The technology allows for the creation of a family of products for different clinical indications and different animal species, including large animals, such as horses or camels.

The second product is Charlie Care, a postoperative collar for dogs. Its patented design offers multiple uses, size ranges and compactness for storage and transportation. In contrast to the standard solutions, dogs can move and eat without restrictions and access to the wound is significantly reduced, which contributes to a faster recovery. Products also differ from competing designs because of a well-planned marketing approach.

The third product, Smart Jockey, was developed in two stages. Initially, a solution to track the condition of a horse's limbs was developed. The issue with the limbs is significant in the veterinary industry; in the majority of cases, it is impossible to restore a limb after an injury or fracture. In the second stage, a system for monitoring the preparation of the horse for professional performances, tracking its progress and achieving an optimal state for a specific period was developed.

\section{Findings}

During the interviews, we concentrated on questions related to the key parameters that support the formation and development of the collaboration between opinion leaders and start-ups. Table 2 offers a summary of these indicators. We also discussed the importance of each of these indicators and asked participants to rank their importance (low, medium and high) for the success of the cooperation.

The interest in cooperation was demonstrated by TraceRay and Opinion leader 1 in the case of intelligent veterinary implants. The key parameters of the cooperation were innovativeness of the product and the ability to solve a global problem in the focal industry. The opinion leader noted that "veterinarians have been solving this problem in the same way for 20 years." During this period, the details were changed, but not the concept. Moreover, none of the veterinarians suspected that the problem could be solved another way. In turn, the start-up had little clinical expertize to solve such problems. As noted by the CTO, TraceRay could choose one of the shortest paths for the $\mathrm{R} \& \mathrm{D}$ process. In this case, based on collaboration with opinion leaders, an industrial problem was identified and a solution proposed that could change the traditional approach in the industry.

In the case of Charlie Care, the company considered the product as an optional accessory and offered an alternate to a traditional plastic cone. Advantages such as durability, reduced use of plastic and design could pique personal but not professional interest in the project. Opinion leader 1 evaluated this device as a "fun addition" to the implant and noted that "the chances for cooperation could be minimized if the company seeks advise on it instead of an implant." However, the existing relationship between the start-up and the opinion leader allowed for cooperation and partial support of the project.

Collaboration of the opinion leader and the Smart Jockey project started because there was interest from both sides. Opinion leader 2 was looking to alleviate the suffering of animals and reduce postoperative complications. It was the opinion leader who pointed out the initial problem, recommended the product design and personally conducted animal tests. The size of the market and the importance of the problem became major factors for collaboration. TraceRay considered the limitations associated with such cooperation based on the intelligent veterinary implants project, and the interaction process proceeded faster than expected. This opinion leader has a greater influence in its region, which affected the geography of sales and development strategies.

During the study, we identified reasons for low interest in cooperation between the start-up and the opinion leader in the Charlie Collar project. The most important parameter was the product's lack of innovation. A parameter as important as the qualification of a team is not sufficient enough for the development of cooperation. The opinion leader considered the project as a "standard solution in designer packaging" and the CEO and project manager noted that it was a "sustainable solution that will increase revenue for the company." Moreover, this solution is less marginal than a product based on university research, and it could be copied by competitors.

TraceRay offers a new approach to $R \& D$ based on collaboration with opinion leaders. At the initial stage of the partnership, the company collaborates as consultants with opinion leaders to discover the problem, and it then offers knowledge of materials and R\&D processes. In particular, the project manager of intelligent veterinary implants stated the following: "we can definitely trust [opinion leader] that this problem is common in the market and not related to the skills."

Further, the focal company continues collaborating with opinion leaders, but they do so as the first testers of the prototypes. After that, the company starts to attract opinion leaders toward product promotion and networking, as mentioned by the CEO: "at conferences, we use articles from peer-reviewed journals to demonstrate the scientific approach and the list of project participants."

Consequently, opinion leaders are the first customers when the product goes on the market. This new approach in the veterinary market considers novel interconnections between the opinion leaders, a new scheme of collaboration and the impact of significant changes on the whole ecosystem (Teece, 2016). Collaboration with opinion leaders and their transformation in time created a new framework for insight in this area.

TraceRay representatives repeatedly emphasize that the direction of product development is constantly influenced by the social capital of opinion leaders; it accumulates over the course of the cooperation and may attract new partners and customers on more favorable terms. The CEO of the company describes it in the following manner:

We have significantly reduced the planned costs associated with product development: the best proposal for conducting mechanical tests was from a regular partner of our opinion leader; for animal tests of implants, we paid 
Table 2 Reasons for collaboration between the start-up and opinion leaders

\begin{tabular}{|c|c|c|c|}
\hline & Intelligent veterinary implants & Charlie Care & Smart Jockey \\
\hline \multicolumn{4}{|c|}{ Reasons for collaboration from the side of the start-up } \\
\hline $\begin{array}{l}\text { The opinion leader's } \\
\text { level of expertize in } \\
\text { research and } \\
\text { development }\end{array}$ & Importance $=$ high & Importance $=$ low & Importance $=$ high \\
\hline Quotes & $\begin{array}{l}\text { The reputation of this vet does not raise } \\
\text { doubts with anyone } \\
\text { We can be sure that his recommendations } \\
\text { for product development or improvements } \\
\text { are } 100 \% \text { based on practice. No chatter, } \\
\text { just facts }\end{array}$ & $\begin{array}{l}\text { He [opinion leader] has little interest in this } \\
\text { project. As it seemed to me, this project } \\
\text { was not ambitious enough for him } \\
\text {... [opinion leader] suggested that we } \\
\text { contact the assistants who are responsible } \\
\text { for postoperative care }\end{array}$ & $\begin{array}{l}\text { Our [opinion leader] has been operating } \\
\text { on dozens of horses per year for the past } \\
30 \text { years }\end{array}$ \\
\hline $\begin{array}{l}\text { Collaboration in } \\
\text { testing on animals }\end{array}$ & Importance $=$ high & Importance $=$ low & Importance $=$ high \\
\hline Quotes & $\begin{array}{l}\text { In this case, we can be sure that the results } \\
\text { of animal tests will not be affected by the } \\
\text { low professional characteristics of the } \\
\text { veterinarian }\end{array}$ & $\begin{array}{l}\text { Our contacts with the veterinary clinic } \\
\text { were reduced to communicating with the } \\
\text { head nurse. She distributed prototypes, } \\
\text { handed out questionnaires and instructed } \\
\text { personnel that used collars }\end{array}$ & $\begin{array}{l}\text { [Opinion leader] with a great passion } \\
\text { responded to the proposal to test } \\
\text { prototypes. He said that he constantly } \\
\text { has horses that have to be euthanized or } \\
\text { amputate limbs }\end{array}$ \\
\hline Product promotion & Importance $=$ high & Importance = low & Importance = medium \\
\hline Quotes & $\begin{array}{l}\text { We have already been presented to the } \\
\text { largest European distributors that } \\
\text { collaborate with [opinion leader]. ... They } \\
\text { are awaiting the test results and the final } \\
\text { version of our solution }\end{array}$ & $\begin{array}{l}\text { We plan to use direct sales and offer our } \\
\text { collar to customers that already } \\
\text { collaborate with TraceRay. We do not plan } \\
\text { to involve [opinion leader] in promotion at } \\
\text { exhibitions or conferences }\end{array}$ & $\begin{array}{l}\text { [Opinion leader] is mostly known in } \\
\text { Spain. This country is the start of our } \\
\text { growth in Europe }\end{array}$ \\
\hline $\begin{array}{l}\text { Co-authorship in peer- } \\
\text { reviewed publications }\end{array}$ & Importance = medium & Importance $=$ low & Importance $=$ low \\
\hline Quotes & $\begin{array}{l}\text { We expect that [opinion leader] will } \\
\text { comment on the manuscripts before } \\
\text { submission. Let's hope that his name will } \\
\text { also contribute to acceptance of an article } \\
\text { in a good journal }\end{array}$ & $\begin{array}{l}\text { There are no plans to write articles about } \\
\text { collars }\end{array}$ & This is not the first priority \\
\hline \multicolumn{4}{|c|}{ Reasons from the side of the opinion leader } \\
\hline $\begin{array}{l}\text { Solution of a } \\
\text { significant problem in } \\
\text { veterinary medicine }\end{array}$ & Importance $=$ high & Importance $=$ low & Importance $=$ high \\
\hline Quotes & $\begin{array}{l}\text { We can change the approach to the } \\
\text { treatment of animals } \\
\text { I decided that the idea for this solution has } \\
\text { potential. A total of } 15 \text { years of university } \\
\text { research and applications in the human } \\
\text { market are important }\end{array}$ & $\begin{array}{l}\text { It was a surprise when they presented a } \\
\text { sketch of the collar. I gave them contacts } \\
\text { in our clinic for tests }\end{array}$ & We can save animals \\
\hline Team of the start-up & Importance $=$ high & Importance $=$ medium & Importance $=$ high \\
\hline Quotes & $\begin{array}{l}\text { I was shocked by the pressure of [the CEO] } \\
\text { at the first meeting. However, later I was } \\
\text { charmed with the competence, innovative } \\
\text { approach and engineering knowledge }\end{array}$ & $\begin{array}{l}\text { I am ready to help the project team, but I } \\
\text { am not ready to devote a lot of time to this }\end{array}$ & $\begin{array}{l}\text { It is good that we have the same goals. I } \\
\text { offer horses and years of experience; they } \\
\text { offer innovations and ideas }\end{array}$ \\
\hline
\end{tabular}

only for consumables, which amounted to about $15 \%$ of the real cost of operations; the first network clinic that started purchasing from us was the clinic where our partner has a practice.

The CTO of the company confirmed this opinion: "the social capital of [opinion leader] forms value for us like a snowball. The further we cooperate, the more value for the market forms for the company and products."

As a consequence of employing opinion leaders and benefiting from their social capital, adopting the company's new products into the market is faster than using the competitors' products, as noted by a private investor who was involved in sales support:

\footnotetext{
The first independent veterinarians as clients came from [opinion leader]. They agreed to become our customers thanks to the reputation of [opinion leader]. After that, customers more easily agreed to cooperate since we already had a position in the market. The same thing happened with distributors. The first distributor was the existing partner of [opinion leader], and then others joined in.
} 
Collaboration with non-opinion leaders is a typical mechanism in B2B practice (Allen, 2012; Thompson, 2013); however, opinion leaders differ from other veterinarians. Apart from being practicing veterinary surgeons, opinion leaders in the veterinary industry could be identified as the leaders or presidium members of professional communities in a country or region. For example, the opinion leader who participated in the first and second projects is one of the leaders of the European Pet Organization. The opinion leader participating in the third project is a leading regional veterinary surgeon and actively participates in the regional development of the industry through two professional associations. Opinion leaders in the veterinary industry are also characterized by additional parameters. On the one hand, their veterinary clinics may not have a significant market share; on the other hand, their opinion is critically important for clinical professionals. The reputation of opinion leaders is based on their contributions to their field of knowledge. This usually includes a large number of publications in professional peer-review journals. In turn, medical journals strictly follow high ethical standards to ensure the quality of publications. The same concept is applied to a product developed with the participation of an opinion leader, as their reputation is at stake with such a product (Casaló et al., 2018; Meskó et al., 2019). Therefore, the degree of trust from clinical professionals is elevated. In fact, the ultimate goal could be an overwhelmingly better product that can drive the competition out and dominate the market. From TraceRay's point of view, cooperation with an opinion leader is more beneficial for a company than cooperation with a big network clinic. The CEO noted:

[Business advisor] recommended that we start a collaboration with a small clinic to test our ideas. However, working with [opinion leader] definitely provides more benefits. First, the experience of an opinion leader far exceeds that of ordinary veterinarians. Second, the cost of cooperation with [opinion leader] is much lower, and this is very important for us.

During the interviews and subsequent analysis, we have identified and analyzed a number of key parameters that support the formation and development of cooperation between opinion leaders and a start-up company. The most important parameters for the opinion leader to collaborate are the significance of the project for the industry and the quality of the start-up team. In turn, the start-up receives the highest level of expertize, assistance in product development and further business support by the opinion leader.

The opinion leaders' motivation for collaboration is different than that of other veterinarians. Opinion leaders are guided by a mission to help animals, as discussed during the interview with opinion leaders 1 and 2:

A lot of animals die from minor injuries. There are no products on the market that solve global problems. (OL1)

Pets and their owners suffer regardless of the money. (OL2)

The main factor of cooperation becomes the expectation of changing or solving a big practical issue. Financial interest decreases, unlike most of the veterinary consultants, as highlighted by the project manager of the intelligent veterinary implants project: "a typical practice veterinarian will invoice you for any phone call. However, they change their attitude if they see [an opinion leader] in the project."
The opinion leader, like the CEO quoted here, is interested in being a trendsetter and bringing innovation to the market: "[opinion leaders] have a different approach [compared to other professional veterinarians]; they have a global vision of the problem. They want to change the world."

However, collaboration with opinion leaders has its drawbacks, one being their involvement in different projects and, as a result, their lack of time. It is complicated to encourage an opinion leader to join the project because of their need to also be involved in clinical practice, the development of their own products and scientific activities. Thus, the process of collaboration and information sharing is slow, as stated by the CTO:

We plan a meeting for three months. In most cases, we have one to two days for which we have to receive answers on many questions, get recommendations and comments, and check new ideas.

In turn, successful collaboration requires a start-up to have certain parameters, the first being team professionalism. Due to lack of time, opinion leaders could lose interest in a project if they notice a lack of competence in a start-up. The team cannot make a mistake in its area of responsibility, as it will be complicated to convince the opinion leader to stay after a mistake is made. The CEO of the company mentions: "we have no right to make mistakes. For our part, we must demonstrate our professionalism; otherwise, we will lose time, money and contacts."

However, the reputation of the opinion leader and their participation in product design, tests, publications and personal experience could become the best recommendation for many professionals. An opinion leader does not sell but recommends solutions to common issues in practice, as investor comments: "we have seen at the exhibition how [an opinion leader] works. He shows the ways of solving practical problems based on his experience."

Companies receive a high level of expertize from the opinion leader, as well as cost reduction in development, tests and sales. Companies can be sure that problems at the R\&D stage did not come from the opinion leader's incompetence. Moreover, veterinarians are more interested in collaborating with the company at different stages of product development if the opinion leader also participates. The project manager commented: "two veterinarians in two countries agreed to participate immediately in product tests when they saw the list of project participants."

\section{Discussion and implications}

Our research is devoted to the adoption of inventions based on the social capital of opinion leaders and start-ups. In conditions of limited resources, start-ups develop individual approaches to value creation and survival. However, social capital creates additional benefits that contribute to the business development of the companies.

The results of our study contribute to the existing marketing literature in two major ways and several minor ones. First, we supplement studies that aim to study the market adoption of innovations (Khoshmaram et al., 2018; Akman et al., 2018). We demonstrate how social capital plays a role in a new product's development, testing and commercialization. The social capital of opinion leaders could be used differently throughout the stages of adoption by gaining expertize, expanding the number of partners and reducing costs.

Start-ups using the social capital of opinion leaders can attract new customers and partners faster than their competitors. 
Potential customers are more loyal to a new product if it is developed with the participation of opinion leaders; the desire to participate in a project or become a customer increases. Additionally, the opinion leaders' social capital promotes the market adoption of a product. On one hand, the first customers started collaborating because an opinion leader was present during product development; they can facilitate the adoption of a product at a level where their reputation and esteem are most prominent, for example, in a certain country or region. On the other hand, potential customers could be ready to use a new product or approach faster because of the number of early adopters (opinion leaders and first customers). Moreover, other important market participants, for example, distributors and service providers, could be influenced by the social capital of the opinion leader, and could therefore, start cooperation on more favorable terms (La Rocca et al., 2019).

Second, our research complements studies that explore collaboration between opinion leaders and companies (Van den Nieuwboer et al., 2016; Truog and Curtis, 2018) by explicating this process in the context of veterinary industry start-ups. We explore how to attract opinion leaders without using significant financial resources and why to choose projects by opinion leaders (Sismondo, 2017). We also identify the most important conditions for starting cooperation and values, both for start-ups and opinion leaders. From the opinion leaders' point of view, these are the significance of the project for the entire industry and the level of the start-up's qualification. The most important outcomes of such collaboration for the start-up are the highest level of expertize at the stage of product development and testing and subsequent networking.

We contribute to the research on forming social capital by studying its role in collaboration when developing innovations (Dearing and Cox, 2018). We demonstrate that the alreadyformed social capital cannot be easily adapted to the needs of new projects. Project parameters, cooperation teams and the project value for the market each play an important role in the use of social capital and the obtained results (Udagedara and Allman, 2019; Krishen et al., 2019). However, cooperation in projects with low market value is also possible if previously established between partners.

We argue that the TraceRay case differs from most of the cooperation between companies and opinion leaders using social capital as the main factor. We determine the conditions for the emergence and development of cooperation without the use of significant financial resources but with mutual interest in the company and opinion leaders to make an impact on the industry. The concept of cooperation between an innovative start-up and opinion leaders can be applied not only by the veterinary market but also by companies from other industries striving for the market adoption of innovations after minor adjustments (Masiello and Izzo, 2019).

Our study also introduces several managerial implications.

First, we offer a number of criteria for starting a collaboration between a start-up and an opinion leader. We explore the different parameters and conclude that product innovation and the qualifications of the founders are dominant. In turn, product innovation is important in combination with a level of the problem for the industry. We also emphasize that product innovation is important for professional society and for attracting opinion leaders that is parameters such as emission reduction or design are less likely to start a collaboration.

Second, further development of cooperation implies an increase in trust between a start-up and an opinion leader. Thus, subsequent projects may be less innovative and industry-changing. The accumulated social capital allows collaboration on products that may not lead to the initial collaboration. Such products may be less valuable to the market; however, they must comply with the overall strategy of the start-up, which was introduced to the opinion leader at the very beginning of the cooperation.

Third, the social capital of an opinion leader could be used as a basis for business development and marketing of the company. At the R\&D stage, one can expect a cost reduction for prototyping and testing products due to the network of the opinion leader. Determining the right path of development reduces the likelihood of failure. An opinion leader is able to support the start of sales through existing contacts with clinics and distributors. Further sales could be supported by cooperation at professional events. Other veterinarians account for the position of opinion leaders because of their reputation in the industry.

We also offer opportunities to identify opinion leaders and determine the value of working with each of them. First, opinion leaders are leaders of professional communities. The more important the community, the more value a start-up could get from such collaboration. In our study, the first opinion leader is an expert at the European level, while the second opinion leader is an expert at the regional level. This parameter played a role at the start of sales. The social capital and network of the first opinion leader helped initiate sales through clinics and distributors in various European countries, while the second opinion leader supported sales only in his own country and in neighboring countries. Second, valuable opinion leaders should have a large number of publications in the best professional journals. Having a professional reputation matters when promoting products at professional conferences and exhibitions. However, a start-up should not expect sales from an opinion leader. Rather, an opinion leader recommends and shares the experience of using the product with others. In addition, we emphasize that the opinion leader is focused on addressing the major challenges that are prevalent in the focal industry. The cash reward is interestingly less compared to a regular veterinarian. Thus, this type of cooperation may be of high interest to start-up companies due to a lack of financial resources.

We also provide practical implications concerning the key parameters that are important for attracting and retaining a leader in the project. We claim that an inadequate team qualification or mistakes during cooperation with an opinion leader may lead to the cooperation's end. However, if the opinion leader continues cooperation with a less competent team, that team could benefit from extra time spent on obtaining expertize from the opinion leader. Waiting for recommendations to attract the opinion leader could negatively affect the likelihood of business success.

\section{Limitations and future research}

This research is one of the few studies devoted to issues of collaboration between opinion leaders and start-ups. Further studies could overcome the existing limitations of our work. 
Primarily, the increased number of companies that create breakthrough products and technologies and facilitate the market adoption of innovations should be analyzed; this analysis will create the possibility to consider trends of collaboration between such companies and opinion leaders. A natural extension of this study would be to evaluate companies at various stages of development and consider changes in their business models based on collaboration with opinion leaders.

\section{References}

Alguezaui, S. and Filieri, R. (2010), "Investigating the role of social capital in innovation: sparse versus dense network", Fournal of Knowledge Management, Vol. 14 No. 6.

Allen, M. (2012), "Advances in total joint replacement in small animals", Fournal of Small Animal Practice, Vol. 53 No. 9, pp. 495-506.

Arfi, W.B. and Hikkerova, L. (2019), "Corporate entrepreneurship, product innovation, and knowledge conversion: the role of digital platforms", Small Business Economics, pp. 1-14.

Armitage-Chan, E. and Jackson, E. (2018), "Improving student engagement in veterinary business studies", fournal of Veterinary Medical Education, Vol. 45 No. 2, pp. 204-212.

Badawi, N.S. and Battor, M. (2020), "Do social capital and relationship quality matter to the key account management effectiveness?", Fournal of Business E Industrial Marketing, Vol. 35 No. 1.

Baum, J. and Silverman, B. (2004), "Picking winners or building them? Alliance, intellectual, and human capital as selection criteria in venture financing and performance of biotechnology startups", fournal of Business Venturing, Vol. 19 No. 3, pp. 411-436.

Baumann, J. and Kritikos, A.S. (2016), "The link between $\mathrm{R} \& \mathrm{D}$, innovation and productivity: are micro firms different?", Research Policy, Vol. 45 No. 6, pp. 1263-1274.

Bennett, W. and Manheim, J.B. (2006), "The one-step flow of communication", The ANNALS of the American Academy of Political and Social Science, Vol. 608 No. 1, pp. 213-232.

Bers, J., Dismukes, J. and Rowe, C. (2014), "Extending the stage-gate model to radical innovation - the accelerated radical innovation model", fournal of the Knowledge Economy, Vol. 5 No. 4, pp. 706-734.

Bocconcelli, R., Cioppi, M., Savelli, E. and Splendiani, S. (2018), "SMEs and marketing: a systematic literature review", International fournal of Management Reviews, Vol. 20 No. 2, pp. 227-254.

Brass, D. and Krackhardt, D. (1999), "The social capital of twenty-first century leaders", Out-of-the-Box Leadership: Transforming the Twenty-First Century Army and Other Top Performing Organizations, pp. 179-194.

Brockman, B.K., Rawlston, M.E., Jones, M.A. and Halstead, D. (2010), "An exploratory model of interpersonal cohesiveness in new product development teams", fournal of Product Innovation Management, Vol. 27 No. 2, pp. 201-219.

Carbonell, P. and Rodríguez Escudero, A.I. (2019), "The dark side of team social cohesion in NPD team boundary spanning", Fournal of Product Innovation Management, Vol. 36 No. 2, pp. 149-171.
Carboni, O.A. and Russu, P. (2018), "Complementarity in product, process, and organizational innovation decisions: evidence from European firms", R\&D Management, Vol. 48 No. 2, pp. 210-222.

Casaló, L., Flavián, C. and Ibáñez-Sánchez, S. (2018), "Influencers on Instagram: antecedents and consequences of opinion leadership", fournal of Business Research, Vol. 117.

Chan, K. and Misra, S. (1990), "Characteristics of the opinion leader: a new dimension", fournal of Advertising, Vol. 19 No. 3, pp. 53-60.

Chesbrough, H. (2010), "Business model innovation: opportunities and barriers", Long Range Planning, Vol. 43 Nos 2/3, pp. 354-363.

Cho, Y., Hwang, J. and Lee, D. (2012), "Identification of effective opinion leaders in the diffusion of technological innovation: a social network approach", Technological Forecasting and Social Change, Vol. 79 No. 1, pp. 97-106.

Chow, W. and Chan, L.S. (2008), "Social network, social trust and shared goals in organizational knowledge sharing", Information \& Management, Vol. 45 No. 7, pp. 458-465.

Coad, A., Grassano, N., Hall, B.H., Moncada-PaternòCastello, P. and Vezzani, A. (2019), "Innovation and industrial dynamics", Structural Change and Economic Dynamics, Vol. 50, pp. 126-131.

Coleman, J. (1988), "Social capital in the creation of human capital”, American fournal of Sociology, Vol. 94, pp. S95-S120.

Coleman, J., Katz, E. and Menzel, H. (1957), "The diffusion of an innovation among physicians", Sociometry, Vol. 20 No. 4, pp. 253-270.

Coombs, J.E. and Bierly, P.E. III (2006), "Measuring technological capability and performance", RED Management, Vol. 36 No. 4, pp. 421-438.

Cooper, R.G. (2019), "The drivers of success in new-product development”, Industrial Marketing Management, Vol. 76, pp. 36-47.

Dakhli, M. and De Clercq, D. (2004), "Human capital, social capital, and innovation: a multi-country study", Entrepreneurship \& Regional Development, Vol. 16 No. 2, pp. 107-128.

Davila, A., Foster, G. and Gupta, M. (2003), "Venture capital financing and the growth of startup firms", Fournal of Business Venturing, Vol. 18 No. 6, pp. 689-708.

Dearing, J. and Cox, J.G. (2018), "Diffusion of innovations theory, principles, and practice", Health Affairs, Vol. 37 No. 2, pp. 183-190.

Denscombe, M. (2014), The Good Research Guide: For SmallScale Social Research Projects, McGraw-Hill Education (UK).

Dubos, R. (2017), Social Capital: Theory and Research, Routledge.

Dutt, N., Hawn, O., Vidal, E. and Mitchell, W. (2016), "How open system intermediaries address institutional failures: the case of business incubators in emerging-market countries", Academy of Management fournal, Vol. 59 No. 3, pp. 818-840.

Eesley, C., Hsu, D. and Roberts, E. (2014), "The contingent effects of top management teams on venture performance: aligning founding team composition with innovation strategy and commercialization environment", Strategic Management fournal, Vol. 35 No. 12, pp. 1798-1817. 
Eisenhardt, K. (1989), "Building theories from case study research", Academy of Management Review, Vol. 14 No. 4, pp. 532-550.

Evans, J.A., Kunda, G. and Barley, S.R. (2004), "Beach time, bridge time, and billable hours: the temporal structure of technical contracting", Administrative Science Quarterly, Vol. 49 No. 1, pp. 1-38.

Fillis, I. (2002), "Small firm marketing theory and practice: insights from the outside", fournal of Research in Marketing and Entrepreneurship, Vol. 4 No. 2, pp. 134-157.

Flammini, S., Arcese, G. and Mortara, L. (2017), "Business model configuration and dynamics for technology commercialization in mature markets”, British Food fournal, Vol. 119 No. 11, pp. 2340-2358.

Flodgren, G., Parmelli, E. and Eccles, M.P. (2007), "Local opinion leaders: effects on professional practice and health care outcomes", Cochrane Database of Systematic Reviews, Vol. 1.

Forti, E., Sobrero, M. and Vezzulli, A. (2020), "Continuity, change, and new product performance: the role of stream concentration", fournal of Product Innovation Management, Vol. 37 No. 3, pp. 228-248.

Fowler, J., Gudmundsson, A. and O'Gorman, J.G. (2007), “The relationship between mentee-mentor gender combination and the provision of distinct mentoring functions", Women in Management Review, Vol. 22 No. 8, pp. 666-681.

Freeman, J. and Engel, J. (2007), "Models of innovation: startups and mature corporations", California Management Review, Vol. 50 No. 1, pp. 94-119.

Frishammar, J., Richtnér, A., Brattström, A., Magnusson, M. and Björk, J. (2019), "Opportunities and challenges in the new innovation landscape: implications for innovation auditing and innovation management", European Management Fournal, Vol. 37 No. 2, pp. 151-164.

Frohlich, M.T. and Westbrook, R. (2001), "Arcs of integration: an international study of supply chain strategies", fournal of Operations Management, Vol. 19 No. 2, pp. 185-200.

Fukuyama, F. (2001), "Social capital, civil society and development", Third World Quarterly, Vol. 22 No. 1, pp. 7-20.

Gabbay, S. and Leenders, R.T.A. (2001), "Social capital of organizations: from social structure to the management of corporate social capital", In Social Capital of Organizations, Emerald Publishing Limited, pp. 1-20.

Gakhar, K. and Chahal, A. (2016), "Role of opinion leadership and communication strategies in innovation, adoption and diffusion", fournal of Management Sciences and Technology, Vol. 3 No. 3, pp. 18-29.

Gans, J. and Stern, S. (2003), "The product market and the market for 'ideas': commercialization strategies for technology entrepreneurs", Research Policy, Vol. 32 No. 2, pp. 333-350.

George, G. (2005), "Slack resources and the performance of privately held firms", Academy of Management fournal, Vol. 48 No. 4, pp. 661-676.

Gilmore, A., Carson, D. and Grant, K. (2001), "SME marketing in practice", Marketing Intelligence \& Planning, Vol. 19 No. 1, pp. 6-11.

Groh, A. (2018), Which Markets Are Sufficiently Mature? Should Investors Wait or Invest Immediately?, The Routledge Companion to Management Buyouts.

Gustavsson, A. Suleman Nasir, A. and Ishonova, S. (2018), "Towards a world of influencers: exploring the relationship building dimensions of influencer marketing",
Heij, C.V., Volberda, H.W., Van den Bosch, F.A. and Hollen, R.M. (2020), "How to leverage the impact of R\&D on product innovation? The moderating effect of management innovation", RED Management, Vol. 50 No. 2, pp. 277-294.

Henry, C., Rushton, J. and Baillie, S. (2016), "Exploring the sustainability of small rural veterinary enterprise", fournal of Small Business and Enterprise Development, Vol. 23 No. 1.

Hoang, H. and Antoncic, B. (2003), "Network-based research in entrepreneurship: a critical review", fournal of Business Venturing, Vol. 18 No. 2, pp. 165-187.

Jack, S. (2005), "The role, use and activation of strong and weak network ties: a qualitative analysis", fournal of Management Studies, Vol. 42 No. 6, pp. 1233-1259.

Jack, S.L. and Anderson, A.R. (2002), "The effects of embeddedness on the entrepreneurial process", Fournal of Business Venturing, Vol. 17 No. 5, pp. 467-487.

Jayashankar, P., Nilakanta, S., Johnston, W. and Burres, R. (2018), "IoT adoption in agriculture: the role of trust, perceived value and risk", fournal of Business $\mathcal{E}$ Industrial Marketing, Vol. 33 No. 6.

Jeong, D., Lee, K. and Cho, K. (2018), "Relationships among international joint research, knowledge diffusion, and science convergence: the case of secondary batteries and fuel cells", Asian Fournal of Technology Innovation, Vol. 26 No. 2, pp. 246-268.

Julien, P. (2018), The State of the Art in Small Business and Entrepreneurship, Routledge.

Katz, E., Lazarsfeld, P. and Roper, E. (2017), Personal Influence: The Part Played by People in the Flow of Mass Communications, Routledge.

Khoshmaram, M., Shiri, N. and Savari, M. (2018), "Environmental support and entrepreneurial behavior among iranian farmers: the mediating roles of social and human Capital", fournal of Small Business Management.

King, N. (2004), "Social capital and nonprofit leaders", Nonprofit Management and Leadership, Vol. 14 No. 4, pp. 471-486.

Kostova, T. and Roth, K. (2003), "Social capital in multinational corporations and a micro-macro model of its formation", Academy of Management Review, Vol. 28 No. 2, pp. 297-317.

Krishen, A., Leenders, M., Muthaly, S., Ziółkowska, M. and LaTour, M. (2019), "Social networking from a social capital perspective: a cross-cultural analysis", European fournal of Marketing, Vol. 53 No. 6, pp. 1234-1253.

Krotz, F. (2009), "Mediatization: a concept with which to grasp media and societal change", Mediatization: Concept, Changes, Consequences, pp. 21-40.

Kumar, N., Yakhlef, A. and Nordin, F. (2019), "Validation of organizational innovation as a creative learning process", Fournal of Business E Industrial Marketing, Vol. 34 No. 3.

La Rocca, A., Perna, A., Sabatini, A. and Baraldi, E. (2019), "The emergence of the customer relationship portfolio of a new venture: a networking process", fournal of Business $\mathcal{G}$ Industrial Marketing, Vol. 34 No. 5.

Lang, D., Handley, M. and Jablokow, K. (2018), "The competencies of innovation leaders", Innovation Leadership, pp. 15-28.

Laurell, H. (2018), “An international new venture's commercialization of a medical technology innovation", International Marketing Review, Vol. 35 No. 1. 
Lazarsfeld, P. Berelson, B. and Gaudet, H. (1944), "The people's choice".

Liberati, A. and Magrini, N. (2003), "Information from drug companies and opinion leaders: double standards in information for medical journals and practitioners should go", BMF, Vol. 326 No. 7400, p. 1156.

Lin, N. (2017), "Building a network theory of social capital”, In Social Capital, Routledge, pp. 3-28.

Lindiwe, O. (2017), "Business and sustainability: towards a new social contract", Fournal of Sustainable Development, Vol. 3 No. 1, pp. 2-10.

Lindstrand, A., Melén, S. and Nordman, E.R. (2011), "Turning social capital into business: a study of the internationalization of biotech SMEs", International Business Review, Vol. 20 No. 2, pp. 194-212.

Locke, K. (2000), Grounded Theory in Management Research, Sage.

Lopez-Nicolas, C., Nikou, S., Molina-Castillo, F.J. and Bouwman, H. (2020), "Gender differences and business model experimentation in European SMEs", fournal of Business Eீ Industrial Marketing, Vol. 35 No. 7.

Lukas, B.A. and Ferrell, O.C. (2000), "The effect of market orientation on product innovation", Fournal of the Academy of Marketing Science, Vol. 28 No. 2, pp. 239-247.

McGowan, P., Cooper, S. and O'Kane, C. (2015), "The influence of social and human capital in developing young women as entrepreneurial business leaders", fournal of Small Business Management, Vol. 53 No. 3, pp. 645-661.

McKeever, E., Anderson, A. and Jack, S. (2014), "Entrepreneurship and mutuality: social capital in processes and practices", Entrepreneurship E Regional Development, Vol. 26 Nos 5/6, pp. 453-477.

Magno, F. and Cassia, F. (2019), "Establishing thought leadership through social media in B2B settings: effects on customer relationship performance", fournal of Business $\mathcal{E}$ Industrial Marketing, Vol. 35 No. 3.

Masiello, B. and Izzo, F. (2019), "Interpersonal social networks and internationalization of traditional SMEs", Fournal of Small Business Management, Vol. 57 No. sup2.

Merton, R.K. (1949), "On sociological theories of the Middle range, na".

Meskó, B., Radó, N. and Győrffy, Z. (2019), “Opinion leader empowered patients about the era of digital health: a qualitative study", BMF Open, Vol. 9 No. 3, p. e025267.

Mishina, Y., Pollock, T. and Porac, J.F. (2004), "Are more resources always better for growth? Resource stickiness in market and product expansion", Strategic Management Fournal, Vol. 25 No. 12, pp. 1179-1197.

Momtaz, N., Aghaie, A. and Alizadeh, S. (2011), "Identifying opinion leaders for marketing by analyzing online social networks", International fournal of Virtual Communities and Social Networking (IFVCSN), Vol. 3 No. 3, pp. 19-34.

Muñoz-Bullon, F., Sanchez-Bueno, M. and Vos-Saz, A. (2015), "Startup team contributions and new firm creation: the role of founding team experience", Entrepreneurship $\mathcal{E}$ Regional Development, Vol. 27 Nos 1/2, pp. 80-105.

Nahapiet, J. and Ghoshal, S. (1998), "Social capital, intellectual capital, and the organizational advantage", Academy of Management Review, Vol. 23 No. 2, pp. 242-266.
Neill, C., Holcomb, R. and Brorsen, B. (2018), "Current market conditions for veterinary services in the US", Applied Economics, Vol. 50 No. 60, pp. 6501-6511.

Onyx, J. and Bullen, K. (2000), "Measuring social capital in five communities", The fournal of Applied Behavioral Science, Vol. 36 No. 1, pp. 23-42.

Pearson, C., Butler, A. and Murray, Y. (2018), "Understanding veterinary leadership in practice”, Veterinary Record, Vol. 182, No. 16, pp. 1-7.

Pertuz, V. and Pérez, A. (2020), "Innovation management practices: review and guidance for future research in SMEs", Management Review Quarterly, pp. 1-37.

Pirolo, L. and Presutti, M. (2010), "The impact of social capital on the start-ups' performance growth", fournal of Small Business Management, Vol. 48 No. 2, pp. 197-227.

Putnam, R. (1993), Making Democracy Work, Princeton University Press, Princeton NJ.

Putnam, R. (2001), Bowling Alone: The Collapse and Revival of American Community, Simon and Schuster.

Ramadani, V., Hisrich, R.D., Abazi-Alili, H., Dana, L.P., Panthi, L. and Abazi-Bexheti, L. (2019), "Product innovation and firm performance in transition economies: a multi-stage estimation approach", Technological Forecasting and Social Change, Vol. 140, pp. 271-280.

Raymond, L. and St-Pierre, J. (2010), "R\&D as a determinant of innovation in manufacturing SMEs: an attempt at empirical clarification", Technovation, Vol. 30 No. 1, pp. 48-56.

Reddy, S.M., Torphy, K., Liu, Y., Chen, T. and Montambault, J.R. (2019), "How different forms of social capital created through project team assignments influence employee adoption of sustainability practices", Organization and Environment, p. 1086026619880343.

Roberts, L. (2017), "Scopes: economics and entrepreneurship: changing the face of veterinary medicine, spring 2017",

Sadik-Rozsnyai, O. and Bertrandias, L. (2019), "New technological attributes and willingness to pay: the role of social innovativeness", European fournal of Marketing, Vol. 53 No. 6, pp. 1099-1124.

Sahelices-Pinto, C. and Rodríguez-Santos, C. (2014), "EWoM and 2.0 opinion leaders", Fournal of Food Products Marketing, Vol. 20 No. 3, pp. 244-261.

Sanchez-Ruiz, P., Daspit, J. and Rutherford, M.W. (2019), "Family social capital in the family firm: a taxonomic classification, relationships with outcomes, and directions for advancement”, Family Business Review, Vol. 32 No. 2, pp. 131-153.

Sarangee, K.R., Schmidt, J.B. and Calantone, R.J. (2019), "Anticipated regret and escalation of commitment to failing, new product development projects in business markets", Industrial Marketing Management, Vol. 76, pp. 157-168.

Schäfer, M. and Taddicken, M. (2015), “Opinion leadership | mediatized opinion leaders: new patterns of opinion leadership in new media environments?", International Fournal of Communication, Vol. 9, p. 22.

Schiavone, F. and Simoni, M. (2019), "Strategic marketing approaches for the diffusion of innovation in highly regulated industrial markets: the value of market access", fournal of Business E Industrial Marketing, Vol. 34, No. 7. 
Schumpeter, J. (1942), "Creative destruction", Capitalism, Socialism and Democracy, Vol. 825, pp. 82-85.

Schwab, A. and Miner, A.S. (2008), "Learning in hybrid-project systems: the effects of project performance on repeated collaboration", Academy of Management fournal, Vol. 51 No. 6, pp. 1117-1149.

Seidel, V.P. (2007), "Concept shifting and the radical product development process", fournal of Product Innovation Management, Vol. 24 No. 6, pp. 522-533.

Semrau, T. and Hopp, C. (2016), "Complementary or compensatory? A contingency perspective on how entrepreneurs' human and social capital interact in shaping start-up progress", Small Business Economics, Vol. 46 No. 3, pp. 407-423.

Shah, S. and Corley, K. (2006), "Building better theory by bridging the quantitative-qualitative divide", fournal of Management Studies, Vol. 43 No. 8, pp. 1821-1835.

Sismondo, S. (2017), "Hegemony of knowledge and pharmaceutical industry strategy", In Philosophical Issues in Pharmaceutics, Springer, Dordrecht, pp. 47-63.

Sismondo, S. and Chloubova, Z. (2016), "You're not just a paid monkey reading slides: how key opinion leaders explain and justify their work", BioSocieties, Vol. 11 No. 2, pp. 199-219.

Song, M. and Thieme, R.J. (2006), “A cross-national investigation of the R\&D-marketing interface in the product innovation process", Industrial Marketing Management, Vol. 35 No. 3, pp. 308-322.

Sternad, D., Krenn, M. and Schmid, S. (2019), "Business excellence for SMEs: motives, obstacles, and size-related adaptations", Total Quality Management \& Business Excellence, Vol. 30 No. 1-2, pp. 151-168.

Sykes, H. and Block, Z. (1989), "Corporate venturing obstacles: sources and solutions", fournal of Business Venturing, Vol. 4 No. 3, pp. 159-167.

Teece, D.J. (2016), "Business ecosystem", The Palgrave Encyclopedia of Strategic Management, pp. 1-4.

Thompson, Z.M. (2013), "Analysis of variability in regulatory requirements for product approval, manufacturing, and post-market surveillance of human and veterinary medical devices in the United States", Doctoral dissertation, University of Georgia.

Truog, R. and Curtis, J. (2018), "Conflicts of interest in critical care partnerships: Are we living up to our values?”, Intensive Care Medicine, Vol. 44 No. 10, pp. 1730-1731.

Tsai, W. and Ghoshal, S. (1998), "Social capital and value creation: the role of intrafirm networks", Academy of Management Fournal, Vol. 41 No. 4, pp. 464-476.

Turner, N., Aitken, J. and Bozarth, C. (2018), “A framework for understanding managerial responses to supply chain complexity", International fournal of Operations \& Production Management, Vol. 38, No. 6.

Udagedara, R. and Allman, K. (2019), "Organizational dynamics and adoption of innovations: a study within the context of software firms in Sri Lanka”, Fournal of Small Business Management, Vol. 57 No. 2, pp. 450-475.
Valdez, G., Kurylo, J. and Mancini, D. (2018), “An overview of manager experience within veterinary institutions", Fournal of Marketing and Management, Vol. 9 No. 1, pp. 13-26.

Van de Ven, A., Hudson, R. and Schroeder, D.M. (1984), "Designing new business startups: entrepreneurial, organizational, and ecological considerations", fournal of Management, Vol. 10 No. 1, pp. 87-108.

Van den Nieuwboer, M., Van De Burgwal, L. and Claassen, E. (2016), "A quantitative key-opinion-leader analysis of innovation barriers in probiotic research and development: valorisation and improving the tech transfer cycle", PharmaNutrition, Vol. 4 No. 1, pp. 9-18.

Walter, A., Ritter, T. and Gemünden, H.G. (2001), "Value creation in buyer-seller relationships: theoretical considerations and empirical results from a supplier's perspective", Industrial Marketing Management, Vol. 30 No. 4, pp. 365-377.

Woolcock, M. and Narayan, D. (2000), "Social capital: implications for development theory, research, and policy", The World Bank Research Observer, Vol. 15 No. 2, pp. 225-249.

$\mathrm{Xu}$, Y. (2016), "Entrepreneurial social capital, cognitive orientation and new venture innovation", Management Research Review, Vol. 39 No. 5, pp. 498-520.

Yin, R. (2011), Applications of Case Study Research, Sage.

Zarei, M., Talebi, S. and Zarei, B. (2019), "Diagnosing entrepreneurial networks: using failure mode and effect analysis", International fournal of Business Excellence, Vol. 17 No. 3, pp. 361-383.

Zhang, L., Zhao, J. and Xu, K. (2015), "Who creates trends in online social media: the crowd or opinion leaders?", fournal of Computer-Mediated Communication, Vol. 21 No. 1, pp. 1-16.

\section{Further reading}

Birley, S. (1985), "The role of networks in the entrepreneurial process", fournal of Business Venturing, Vol. 1 No. 1, pp. 107-117.

Brüderl, J. and Preisendörfer, P. (1998), "Network support and the success of newly founded business", Small Business Economics, Vol. 10 No. 3, pp. 213-225.

Granovetter, M.S. (1977), "The strength of weak ties", In Social Networks, Academic Press, pp. 347-367.

Inkeles, A. (2001), "Measuring social capital and its consequences", In Social Capital as a Policy Resource, Springer, Boston, pp. 19-42.

Molina-Morales, F.X. and Martínez-Fernández, M.T. (2010), "Social networks: effects of social capital on firm innovation", Fournal of Small Business Management, Vol. 48 No. 2, pp. 258-279.

\section{Corresponding author}

Ignat Kulkov can be contacted at: ignat.kulkov@abo.fi 